\title{
Professional Agency for Learning as a Key for Developing Teachers' Competencies?
}

\author{
Auli Toom ${ }^{1, *(\mathbb{C}}$, Kirsi Pyhältö ${ }^{1} \mathbb{D}$, Janne Pietarinen ${ }^{2} \mathbb{D}$ and Tiina Soini ${ }^{3} \mathbb{C}$ \\ 1 Centre for University Teaching and Learning, University of Helsinki, 00100 Helsinki, Finland; \\ kirsi.pyhalto@helsinki.fi \\ 2 Philosophical Faculty, University of Eastern Finland, 80101 Joensuu, Finland; janne.pietarinen@uef.fi \\ 3 Faculty of Education and Culture, Tampere University, 33100 Tampere, Finland; tiina.soini-ikonen@tuni.fi \\ * Correspondence: auli.toom@helsinki.fi
}

check for updates

Citation: Toom, A.; Pyhältö, K.; Pietarinen, J.; Soini, T. Professional Agency for Learning as a Key for Developing Teachers' Competencies? Educ. Sci. 2021, 11, 324. https:// doi.org/10.3390/educsci11070324

Academic Editor: Eila Jeronen and Kirsi Tirri

Received: 2 May 2021

Accepted: 22 June 2021

Published: 29 June 2021

Publisher's Note: MDPI stays neutral with regard to jurisdictional claims in published maps and institutional affiliations.

Copyright: (c) 2021 by the authors. Licensee MDPI, Basel, Switzerland. This article is an open access article distributed under the terms and conditions of the Creative Commons Attribution (CC BY) license (https:/ / creativecommons.org/licenses/by/ $4.0 /)$.

\begin{abstract}
Teacher's professional competencies have been discussed extensively in the literature, often linked to educational policy discourses, teaching standards, student learning outcomes, or the intended outcomes of teacher education. Extensive, but fragmented and loosely theoretically or empirically based lists of teacher competencies are provided without much clarification of how, when, and why teachers learn and identify the competencies they need. Teacher competencies and how they are related to the core of their work as thinking practice have been discussed extensively by a range of stakeholders. However, what is actually needed in order to attain such competencies has been less studied. This paper contributes to the gap in the literature on active and intentional learning of teacher competencies by elaborating the relationship between teacher competencies and professional agency for learning. Through this, our aim in this article is to provide a better understanding of the topic, both theoretically and empirically. Drawing on earlier research, we have elaborated on the relationships between a teacher's professional competencies and agency for learning among pre- and in-service teachers. We also aim to answer the question: what characteristics of teacher education lead to student teachers becoming competent and agentic? Why should we focus on those features during pre-service teacher education and as part of a teacher's career?
\end{abstract}

Keywords: teacher's professional agency; teacher competencies; teacher education; learning; professional development

\section{Introduction}

Professionally competent and agentic teachers are expected to enhance instructional quality, meet students' needs, promote positive educational trajectories, school development, and pedagogical innovations [1-4]. The need for such qualities has been highlighted by researchers, practitioners, and policy makers [5,6]. In fact, competence has become a prominent part of educational policy discourse on teachers and their professional development, typically realized in extensive lists of teacher competence requirements. Interestingly, it seems that much of the research has adopted an approach similar to relying on the fragmented and loosely theoretically, empirically, or contextually-based lists of desired teacher competencies or even just drawing on OECD policy reports [7]. Less attention has been paid on how, when, and why teachers learn these competencies, how they are related to the core of teacher work as thinking practice [1], and what is needed in order to attain such competencies. More recently, teacher agency has been highlighted, particularly in the literature on school development, with teacher learning as a key to enhancing teacher commitment to continuing professional development and school development [8]. Research on teacher agency typically highlights the importance of a teacher's autonomy and active role in decision-making in regard to different aspects of their work [9]

There are several commonalities between research on a teacher's professional competencies and professional agency. Both of them tackle the complexity of teacher cognition 
and behaviour [10-12], utilising elements of teacher knowledge in a sense that it emphasises the importance of the professional knowledge base for teaching $[13,14]$. In line with research on the 'reflective practitioner', they both emphasize continuous consideration of one's own and others' thoughts and behaviours as a key activity for developing in the teaching profession. Moreover, both professional competencies and professional agency are dynamic and constantly constructed $[15,16]$. Beyond these, the research trajectory on a teacher's professional agency perceives teachers as active learners with motivation to study efficacy beliefs of learning, and intentional acts for promoting knowledge [9,17], which primarily takes place in classrooms and in professional communities in schools. Research on a teacher's professional agency also recognises the professional interactions and contexts as integral and genuine elements for a teacher's agency and encourages investigating them [18].

Although research on teacher competencies and teacher agency have much in common, they are typically studied as separate constructs. Accordingly, the relationship between a teacher's professional agency for learning and knowledge of competencies for a teacher's work has not been systematically elaborated. Moreover, although extensively referred to in the literature, empirical studies tackling the question of teacher agency are still relatively rare. This paper contributes to the gap in the literature on active and intentional learning of teacher competencies by elaborating the relationship between teacher competencies and professional agency for learning. Our stance on teacher competencies stems from empirical research defining them as integrative constructs, including cognitive, motivational, and behavioural aspects i.e., knowledge, skills, and attitudes [16]. The competencies are learned, and provide core resources for a teacher's work. The professional agency, on the other hand, in addition to being a teacher's core capability in the sense that it offers a key for active and skilful teacher learning, also provides understanding of the dynamics of the preconditions for such learning in their work [15]. Yet, professional agency embodies a capacity that allows teachers to learn actively and skilfully, regulate their own learning, learning competencies needed in their work, develop professionally, promote students' and colleagues' learning, as well as innovate and promote change in schools [15]. Drawing on the socio-constructivist view on learning, in this article, our aim is to provide a better understanding of learning of teacher competencies, both theoretically and empirically by analysing their relationship. These constructs have been elaborated theoretically and investigated empirically in earlier research, but they have not been systematically analysed together before. Drawing on earlier research and empirical evidence, the relationship between a teacher's professional competencies and agency for learning during teacher education and in the profession is highlighted in this article, with focus on the former.

\section{Teacher's Professional Competencies for the Work of Teaching}

Teacher's competencies are often understood as integrative and complex constructs, including knowledge, skills, and disposition to act in professional situations $[2,3,19,20]$. In a theoretical and descriptive sense, competencies are cognitive structures that support certain teacher behaviours, and in an operational sense, competencies cover a variety of skills, allowing a teacher to act in complicated and changing professional situations, and finding solutions to them $[2,16,20]$. They are perceived as dynamic structures necessary for successful teaching $[7,21]$. Competencies are suggested to capture the core qualities of teachers' work, but lack clear operational definition $[7,20]$ and focus. A range of "researchinformed views on the teacher competence concept strive to find common ground beyond different cultural traditions, defining key knowledge, skills and attitudes that can be required of teachers, the role of professional standards, and basic characteristics of teacher expertise" [7]. This is due to the need to utilise the concept in empirical research work.

A variety of models and even lists of a teacher's core competencies, either as criteria for high quality teaching in classrooms and schools or as outcomes of pre-service or in-service teacher education, have been provided $[17,22]$. The fundamental premise for defining teacher competencies tends to emerge from the authenticity of teaching [23], identification 
of the core characteristics of the practice of teaching, and analysis of teachers' broader professional tasks and responsibilities in society [24-27] currently and in the future. Thus, the close connection to the practice of teaching is common to all theorizations of teacher competencies [21], focusing primarily on the teachers' necessary capabilities for enhancing student learning, though the emphases of competencies are varied. The theorisations aim at being empirically relevant for research purposes. The models of teacher competencies especially aim at capturing teachers' necessary capabilities for facilitating the learning process and enhancing student learning. There exists a number of teachers' core competencies, which strive to define the necessary resources for teachers $[28,29]$. They tend to specify declarative and procedural pedagogical and subject-specific knowledge, value basis, motivational and reflective aspects, and professional development in teaching [22,25,30]. In addition, student-centred teaching, use of digital technologies, and teachers' professional collaboration are typically emphasized in the literature on competencies [31,32]. Some theorizations on teacher competencies focus on the classroom level, others stretch to the collegial and school levels, or even beyond. Some of the models are-without very strong empirical evidence or justifications-linked to national teaching standards and are explicated as the basis, learning goals, or outcomes for teacher education curricula [28]. Due to the lack of solid theoretical grounding or empirical evidence, these cannot be utilised in empirical research.

Many of the teacher competencies listed are discussed and elaborated in educational policy documents, while few of them rise from empirical research evidence. As such, they reflect evidence-based or research-informed understanding of quality teaching, good teachers' capabilities, and current (development) needs identified in schools. Thus, they are also presented normatively as characteristics and criteria for good teachers and teaching without a solid empirical foundation and research basis. These kinds of theorisations of teacher competencies are often linked to the current and changing demands of teacher accountability. At the same time, discussion (and even the research) is heavily driven by educational policies. Problems may arise if policy-driven conceptualisations of teacher competencies without having empirical evidence are applied in empirical research on teachers and teaching. As such, the requirements are more or less externally defined and do not give any advice to teachers on learning these competencies, or how they could facilitate other teachers' learning. Research on the learning of competencies during teacher education or in the profession is quite limited [3]. There is a limited number of studies investigating competencies as a continuum or gradually increasing capabilities leading to expertise in teaching $[21,33,34]$. This shows that the field of teacher competencies is relatively scattered, and a variety of understanding, approaches, and definitions of teacher competencies exists.

After finalizing pre-service teacher education, achieving professional competencies is primarily grounded in everyday work. From this perspective, it is crucial to identify what student teachers need to learn during teacher education in order to work and learn continuously in the teaching profession. What are the current conditions and what will they be in the future, for which student teachers would need to be prepared? How should student teachers' learning be supported during teacher education in a reasonable and sustainable way [30,35]? What professional agency should student teachers learn during teacher education so that they can regulate their own learning and be capable and competent throughout their career?

\section{Teacher's Professional Agency for Learning in Classroom and Professional Community}

Our approach on a teacher's professional agency for learning draws on the socioconstructivist view on learning, which we have empirically confirmed in our own research, and it refers to a teacher's intellect and the behavioural capacity needed for intentional and accountable orchestration of learning in a variety of contexts [9,36-39]. It entails the motivation to learn, efficacy beliefs of learning, and intentional acts for promoting one's own learning, colleagues' learning, student learning, and school development $[9,17,40]$. 
Thus, professional agency is an integrative concept comprising a teacher's cognitive, motivational, and attitudinal resources, as well as skills and abilities to promote and manage learning in a variety of professional contexts, particularly in the classroom with students and in the professional community with colleagues [41]. This entails self- and co-regulation of learning with and for the students and within the school community at large [42-44]. Professional agency can vary between the teachers and over time in various periods of the teaching career [45]. Accordingly, professional agency is not a permanent teacher trait. Rather, according to our understanding, it is constantly evolving via learning and as a result of the teacher-working environment dynamics. Thus, according to our view, a teacher's professional agency is neither only about the teacher's individual characteristics or traits as it is typically understood in purely psychological approaches, nor only about the institutional structures and power relations as it is often presented in sociological theorisations and approaches on human and professional agency [9]. Purely psychological or sociological approaches on agency in general and teacher agency emphasise different aspects of agency due to their fundamental premises, and thus, are realised in tensions between the different definitions. Consequently, a teacher's professional agency for learning is constantly constructed and re-constructed in a variety of contexts, objects of activity, and prior learning experiences $[46,47]$. With the aim of supporting student learning, identifying one's own and others' learning needs, learning professional competencies themselves, engaging in continuous professional development, and promoting pedagogical innovations and school developments, teachers need professional agency in the classroom, but also in their work community [9].

Professionally agentic teachers are characterized by perceiving learning as a fundamental part of their teaching [48], having an active and accountable stance for their own and others' learning and being motivated to develop professionally $[8,37,39]$. They perceive others as elemental resources for their own learning and are ready to invest their own resources for the best of individual and reciprocal collaborative learning processes $[49,50]$. Intentional self- and co-regulation of learning allow teachers to evaluate their own and others' learning and adjust their development towards better achievements in terms of their profession [9]. It allows teachers to identify their own learning needs and learn professional competencies they perceive that they lack. Teachers' strong sense of professional agency is realized in their understanding and will to enhance reciprocal learning with students and colleagues, experiment and integrate innovations to their teaching, develop through joint professional work, solve challenges together, build a professional community, utilize feedback from others, and support peers as well as be able to be supported $[9,15]$. This is related to their perceptions of themselves as teachers, how they are likely to promote others' learning, and develop their own pedagogical practices [51].

A teacher's professional agency is realized primarily in the classroom and in the professional community, which are the fundamental contexts of their work and in which the object of professional agency—students' learning, colleagues' learning and their own learning - is realised. Agentic teachers understand instruction as a reciprocal process in which they support students' learning, but also perceive students as resources for their own professional learning. Pedagogical interactions and practices allow and challenge teachers to reflect on their work and development continuously $[52,53]$. In the professional community, professional agency is about being responsible for their own learning and that of others, building a professional community intentionally, and facilitating collective efficacy among colleagues in terms of professional learning. This involves collective learning and even transformative efforts that are intended to make a difference both at the level of individual teachers and that of the entire teacher community [54]. Professional agency in the classroom and in the professional community are related both to the characteristics of individual teachers and their reciprocal relationships with others [55]. Thus, it is always situative and constructed in social interactions, implying that not all resources and opportunities for learning can be fruitfully utilized due to personal and contextual conditions. Professional agency is dynamic, and its development is regulated by a variety 
of internal and external factors in a teacher's work [15]. As such, it is highly dependent on the teacher-working environment dynamics and cannot be reduced into either the individual teacher or the working environment attributes.

Results from some earlier studies also indicate that a teacher's professional agency is crucial for commitment to their work, students' learning, and agency development, but also towards school development and others' learning [56-59]. A teacher's professional agency is also shown to be related to decreased stress [9] and openness to innovative ideas [60,61]. Hence, teachers' capacity to transform their work intentionally and collectively is essential in terms of enhancing professional collaboration in their work.

To conclude, a teacher's professional agency provides an empirically-based conceptual tool with which to analyse and understand teacher learning. In contrast to teachers' professional competencies, it does not provide any perspectives on what teachers should learn.

\section{Enhancing a Teacher's Professional Agency and Meaningful Learning of Competencies in Teacher Education and in the Profession}

A teacher's professional agency is not only an individual trait, and accordingly, the professional agency both in the classroom and in the professional community can be learnt from the beginning of teacher education throughout the teaching career $[9,15,62]$. Teachers can also learn how to support others' agency. We perceive teachers' professional agency as a key capability required in a teacher's work: a key for their own, their colleagues', and pupils' learning and development. It brings a perspective of learning research into the discussion and allows to perceive teachers as active, responsible, and accountable professionals. We investigated its development among student teachers, early career teachers, and expert teachers. Since teacher learning is relational and contextual, the professional agency can be considered to be highly socially embedded and hence grounded in the interaction between teachers and students, and in general in the variety of contexts provided by the teacher's work and teacher education $[36,47,63]$. Teacher education learning environments and working contexts are continuously constructed through a variety of social interactions and practices that either significantly enhance or impede teachers' professional agency $[9,17,42]$. Based on our empirical research, we know that constructive interactions and social relationships providing opportunities for participation, enhancing engagement, and calling for everyone's contributions, are favourable for the development of a teacher's professional agency [47]. Well-functioning interactions with peers, respectful interactions, and equal opportunities for participation in teacher education are crucial in cultivating professional agency among student teachers $[9,17]$. Taking students' or colleagues' learning needs into account and building learning environments together is not easy. These may take time and definitely require identifying one's own learning needs and learning certain competencies beyond motivation and efficacy to do so.

Even at its best, a teacher's professional agency develops gradually during teacher education if student teachers are intentionally encouraged to act as professionals with an accountable stance towards their work [47]. Ideally, while learning to become a professional teacher, student teachers gradually cultivate their professional agency, including motivation, self-efficacy, and skills for promoting learning [9]. Student teachers' sense of professional agency in the classroom consists of learning in terms of reflection, modelling, building a collaborative learning environment, and competence, which are shown to be firmly related to and dependent of each other [53]. In addition, these modes of a teacher's professional agency change in the different phases of teacher education [53], meaning that they are in a reciprocal relationship with each other, and their role is different in different phases of their studies. Early career teachers have also been shown to experience challenges in building constructive classroom interaction [17] and in co-creating professional learning communities [64]. Professional agency calls for active involvement in the work of teaching, not only observing and reflecting on teaching [28,41]; yet mere involvement does not automatically result in professional agency. It is essential that student teachers are provided a variety of possibilities to practice and analyse teaching, as well as experiment with and enact their professional agency with their peers and pupils in the classroom. The 
organization of teacher education and the pedagogies and assessment practices $[35,65]$ utilized in the program influence the capabilities with which student teachers enter the teaching profession. Practices increasing the ability to act in professional situations and reflect on them have been shown to be efficient in teacher learning [66]. These practices simulate and allow to model real professional interactions, and thus encourage learning of professional agency, further resulting in learning of professional competencies. It is important to support student teacher learning in a variety of ways, and practice skills in the classroom repeatedly throughout teacher education [24-26] because learning of professional agency and instructional competencies takes time.

When teachers have the opportunities to encounter and overcome professional challenges with their peers and also with students in a good and safe atmosphere, they are more likely to co-regulate their learning with their peers and students [15,67]. While co-reflecting on their learning, they have the opportunity to identify the competencies they need to learn and build strategies for acquiring these competencies in the future. Positive relationships with peers are associated with efficacy in terms of learning [39] and efforts to promote their learning [68]. An environment that acknowledges teachers' initiatives and facilitates their co-regulated learning also promotes their professional agency $[69,70]$. All these elements contribute to teachers' potential to discover their strengths and areas of development in terms of the learning competencies needed in their work.

On the whole, the practices of the learning environment in teacher education and at work shape professional agency both in the classroom and in the work community [39,71]. It has been shown that tasks and practices requiring participation, co-regulation [15,67], collaboration, and social support [15] allow student teachers to develop their professional agency $[9,72]$. It has been found that significant learning experiences during the first year of studies and the first few years in the profession are necessary in transforming and expanding teachers' views of professional learning and development from the intrapersonal to the interpersonal level. This allows them to learn from each other and function as resources for each other's learning in their education and profession $[9,73]$.

To conclude, a teacher's professional agency as an integrative capacity entailing motivation to learn, efficacy beliefs of learning, and skills for promoting and managing learning in a variety of professional contexts, particularly in the classroom with students and in the professional community, is a prerequisite for learning the professional competencies needed in the teaching profession. Through professional agency, teachers can identify their learning needs and enhance the competencies they individually or collectively perceive as being important. Professional agency allows teachers to learn professional competencies actively and meaningfully in their work based on the observations of the practice of teaching. By combining a teacher's professional agency and professional competencies in research, both the process and outcome of teacher learning can be potentially reached. Accordingly, professionally agentic teacher behaviour entails teachers' evaluation of the object of learning and based on this, selecting the most suitable course of action. This can include reflection on if and what needs to be learnt, which can occasionally also be at odds with the reform goals set by the policies, and lead to active resistance. However, without professional agency and hence the chance to manage one's own learning, professional competencies may remain fragmented, external, and hence less functional [33]. In the worst-case scenario, teachers are left poorly equipped with just external standards for facing the challenges provided by the profession. From this perspective, professional agency challenges the idea of externally pre-set uniform teacher standards-the view that is often embedded in the discourse on teacher competencies. On the other hand, with the professional competencies' component in the research, the perspectives of teacher's work can be better taken into account. The key characteristics and relationship between a teacher's professional agency and professional competencies are presented in Table 1. 
Table 1. Teacher's professional agency as a key capability for learning professional competencies.

\begin{tabular}{|c|c|}
\hline Teacher's Professional Agency & Teacher's Competencies \\
\hline $\begin{array}{l}\text { - Includes will, efficacy, and skills for learning } \\
\text { - } \quad \text { Object of agency is learning } \\
\text { - } \quad \text { Is contextual and relational } \\
\text { - } \quad \text { Teacher defines what she needs to learn } \\
\text { - } \quad \text { Is a prerequisite for meaningful and coherent } \\
\text { teacher learning of professional competencies } \\
\text { - } \quad \text { Descriptive } \\
\text { Does not take a normative stance on what } \\
\text { - } \quad \text { Teachers should learn } \\
\text { and skilfully }\end{array}$ & $\begin{array}{l}\text { - } \quad \text { Includes cognitive and behavioural component } \\
\text { - } \quad \text { Objects and focuses are many } \\
\text { - } \quad \text { personal capabilities } \\
\text { - } \quad \text { strongly externally defined by policy makers, } \\
\text { - } \quad \text { Takes a stance on WHAT teachers should learn }\end{array}$ \\
\hline
\end{tabular}

To sum up, research on professional agency and teacher competencies take complementary but distinct stances on teacher learning. This is also realised in the efforts to combine the approaches and utilise them both in empirical research. They both also carry relatively heavy meanings and even ideological connotations, and thus, utilising them in research may cause further needs to explain and sharpen the definition in order to avoid unnecessary misunderstandings. The differences and similarities of the stances can be summarized as follows: Professional agency constitutes a teacher's will, efficacy, and skills for learning, while competencies are comprised of knowledge, skills, and attitudes. Accordingly, the constructs share the skill component. While the object of professional agency is learning, the objects of competence vary from how to teach mathematics to how to manage the classroom. While professional agency is perceived as being highly relational and contextual, competencies are typically considered to be individual constructs and qualities agreed in collective professional and educational policy discourses. Moreover, the competencies needed by the teachers are typically defined in line with the characteristics of the teacher's work by external stakeholders, such as policy makers, school authorities, and teacher educators, whereas the professional agency draws on the idea of strong teacher autonomy in terms of their own learning. Research on teacher's competencies takes a strong position on what teachers need to learn i.e., what competencies are needed in a teacher's work, while research on professional agency does not take a stance on what teachers should learn, but rather focuses on how they learn actively and skilfully.

\section{Discussion}

A teacher's professional agency and professional competencies are lines of teacher research that provide different conceptual structures for understanding teacher learning. A teacher's professional agency allows an understanding of active and skillful learning [15], whereas a teacher's professional competencies focus on investigating the contents and outcomes of teacher learning $[17,21]$. At their best, these two lines of research can also be perceived as complementing each other. A teacher's professional agency is a fundamental capacity for teachers and necessary to learn during teacher education. It allows teachers to enhance their own and others' learning and professional development as well as innovations and pedagogical developments in the professional community. It also allows teachers to identify and analyse their own learning needs in relation to the professional competencies required in a teacher's work over time, not only adopt distinct external requirements or adapt to the coincidental demands set from the outside. Professional competencies as such describe the key aspects of the work of teaching, but they do not focus on describing or providing tools for ways and processes of a teacher's own learning, or the learning of their colleagues or students. From the viewpoint of research, teacher education, a teacher's work in the profession, and all the choices related to teacher competencies are also value-laden and even ideologically related to the purpose of education that involve educational policy-making in certain educational and societal contexts [74]. In addition, 
for these reasons, a teacher's professional agency, autonomy, and intentional management for their own and other's learning is essential.

When teachers both in pre-service teacher education and in the profession are challenged and provided with a variety of opportunities to try and experience transformative practices, they tend to foster them in their own work as teachers [75]. They also tend to foster agency among their own students [73]. The extent to which teachers learn a strong sense of professional agency during their early years in teacher education is related to their potential to act as empowering professional agents in their own work [47]. Thus, it is crucial that teachers are provided several and repeated opportunities to practice professional agency in teacher education, both with their peers and pupils in the classroom. This assumes a curriculum of teacher education and pedagogies of teacher education as well as teacher educators who are willing and able to provide this kind of learning experiences for student teachers. Enacting professional agency for learning is a long-lasting process that takes place in classroom interaction and in the professional community throughout a teaching career [74]. This is necessary for the teacher's own continuous learning and development in the profession.

From the viewpoint of research on teacher education, we believe it is important to discuss and analyse current emphases in teacher research on professional agency and professional competencies. They reflect the discourses and understandings of a teacher's work and demonstrate the current needs and emphases in research and in the practice of teaching. A teacher's professional agency is based on the conception of teachers as autonomous professionals in terms of their work and learning. It allows an investigation of how teachers learn and does not provide any norms or guidelines for what teachers should learn. IN contrast, research on a teacher's professional competencies is more firmly linked to educational policy discourses on a teacher's capabilities. It is more normative by nature, and thus a more challenging concept for empirical research. When combined, these two separate lines of teacher research could complement each other and pave the way for new comprehensive research lines. The research on ways and substance of teacher learning could solve challenges related to the research field and allow the practice of teaching and teacher education to be improved.

Author Contributions: Conceptualization, A.T., K.P., J.P. and T.S.; investigation, A.T., K.P., J.P. and T.S.; resources, A.T., K.P., J.P. and T.S.; writing-original draft preparation, A.T., K.P., J.P. and T.S; writing-review and editing, A.T., K.P., J.P. and T.S.; visualization, A.T. and K.P.; project administration, A.T., K.P., J.P. and T.S.; funding acquisition, A.T., K.P., J.P. and T.S. All authors have read and agreed to the published version of the manuscript.

Funding: This work was supported by the Academy of Finland [Grant Number 326647].

Institutional Review Board Statement: The study did not involve humans.

Informed Consent Statement: The study did not involve humans.

Data Availability Statement: The study did not involve humans or empirical data.

Acknowledgments: Open access funding provided by University of Helsinki.

Conflicts of Interest: The authors declare no conflict of interest.

\section{References}

1. Lampert, M. Studying Teaching as a Thinking Practice. In Thinking Practices; Greeno, J., Goldman, S.G., Eds.; Lawrence Erlbaum: Hillsdale, NJ, USA, 1998; pp. 53-78.

2. Korthagen, F.A.J. In Search of the Essence of a Good Teacher: Towards a More Holistic Approach in Teacher Education. Teach. Teach. Educ. 2004, 20, 77-97. [CrossRef]

3. Struyven, K.; De Meyst, M. Competence-Based Teacher Education: Illusion or Reality? An Assessment of the Implementation Status in Flanders from Teachers' and Students' Points of View. Teach. Teach. Educ. 2010, 26, 1495-1510. [CrossRef]

4. Pantic, N.; Florian, L. Developing Teachers as Agents of Inclusion and Social Justice. Educ. Inq. 2015, 6, 333-351. [CrossRef]

5. OECD. Teachers Matter: Attracting, Developing and Retaining Effective Teachers; OECD Publications: Paris, France, 2005.

6. Zeichner, K.M. Teacher Education and the Struggle for Social Justice; Routledge: London, UK, 2009. 
7. Caena, F. Teacher Competence Frameworks in Europe: Policy-as-Discourse and Policy-as-Practice. Eur. J. Educ. $2014,49,311-331$. [CrossRef]

8. Priestley, M.; Biesta, G.J.J.; Robinson, S. Teacher Agency: An Ecological Approach; Bloomsbury Academic: London, UK, 2015.

9. Toom, A.; Pyhältö, K.; O'Connell Rust, F. Teacher's Professional Agency in Contradictory Times. Teach. Teach. Theory Pract. 2015, 21, 615-623. [CrossRef]

10. Gage, N. Handbook of Research on Teaching; McNally: Chicago, IL, USA, 1964.

11. Clark, C.M.; Peterson, P.L. Teachers' Thought Processes. In Handbook of Research on Teaching, 3rd ed.; Wittrock, M.C., Ed.; Macmillan: New York, NY, USA, 1986; pp. 255-296.

12. Richardson, V. (Ed.) Handbook of Research on Teaching; American Educational Research Association: Washington, DC, USA, 2004.

13. Shulman, L.S. Those Who Understand: Knowledge Growth in Teaching. Educ. Res. 1986, 15, 4-14. [CrossRef]

14. Fenstermacher, G.D. The Knower and the Known: The Nature of Knowledge in Research on Teaching. In Review of Research in Education, 20; Darling-Hammond, L., Ed.; American Educational Research Association: Washington, DC, USA, $1994 ;$ pp. 3-56.

15. Saariaho, E.; Pyhältö, K.; Toom, A.; Pietarinen, J.; Soini, T. Student Teachers' Self- and Co-regulation of Learning during Teacher Education. Learn. Res. Pract. 2016, 2, 44-63. [CrossRef]

16. Blömeke, S.; Delaney, S. Assessment of Teacher Knowledge across Countries: A Review of the State of Research. ZDM Math. Educ. 2012, 44, 223-247. [CrossRef]

17. Heikonen, L.; Pietarinen, J.; Pyhältö, K.; Toom, A.; Soini, T. Early Career Teachers' Sense of Professional Agency in the Classroom: Associations with Turnover Intentions and Perceived Inadequacy in Teacher-student Interaction. Asia-Pac. J. Teach. Educ. 2017, 45, 250-266. [CrossRef]

18. Cochran-Smith, M.; Villegas, A.M. Research on Teacher Preparation: Charting the Landscape of a Sprawling Field. In Handbook of Research on Teaching, 5th ed.; Gitomer, D.G., Bell, C.A., Eds.; American Educational Research Association: Washington, DC, USA, 2016; pp. 439-548.

19. Koster, B.; Brekelmans, M.; Korthagen, F.; Wubbels, T. Quality Requirements for Teacher Educators. Teach. Teach. Educ. 2005, 21, 157-176. [CrossRef]

20. Westera, W. Competences in Education: A Confusion of Tongues. J. Curric. Stud. 2001, 33, 75-88. [CrossRef]

21. Blömeke, S.; Gustafsson, J.; Shavelson, R.J. Beyond Dichotomies: Competence Viewed as a Continuum. Z. Für Psychol. 2015, 223, 3-13. [CrossRef]

22. Baumert, J.; Kunter, M. Stichwort: Professionelle Kompetenz von Lehrkräften. Z. Für Erzieh. 2006, 9, 469-520. [CrossRef]

23. Hiebert, J.; Morris, A.K.; Berk, D.; Jansen, A. Preparing teachers to learn from teaching. J. Teach. Educ. 2007, 58, 47-61. [CrossRef]

24. Darling-Hammond, L. Constructing 21st Century Teacher Education. J. Teach. Educ. 2006, 57, 300-314. [CrossRef]

25. Pantic, N.; Wubbels, T. Teacher Competencies as a Basis for Teacher Education-Views of Serbian Teachers and Teacher Educators. Teach. Teach. Educ. 2010, 26, 694-703. [CrossRef]

26. Pantic, N.; Wubbels, T. Competence-Based Teacher Education: A Change from Didaktik to Curriculum Culture? J. Curric. Stud. 2012, 44, 61-87. [CrossRef]

27. Pantic, N.; Wubbels, T.; Mainhard, T. Teacher Competence as a Basis for Teacher Education: Comparing Views of Teachers and Teacher Educators in Five Western Balkan Countries. Comp. Educ. Rev. 2011, 55, 165-188. [CrossRef]

28. Munby, H.; Russell, T.; Martin, A.K. Teachers' Knowledge and How It Develops. In Handbook of Research on Teaching, 4th ed.; Richardson, V., Ed.; American Educational Research Association: Washington, DC, USA, 2001; pp. 877-904.

29. Shulman, L.S. Knowledge and Teaching: Foundations of the New Reform. Harv. Educ. Rev. 1987, 57, 1-22. [CrossRef]

30. Gitomer, D.H.; Zisk, R.C. Chapter 1: Knowing What Teachers Know. Rev. Res. Educ. 2015, 39, 1-53. [CrossRef]

31. Kereluik, K.; Mishra, P.; Fahnoe, C.; Terry, R. What Knowledge Is of Most Worth: Teacher Knowledge for 21st Century Learning. J. Digit. Learn. Teach. Educ. 2013, 29, 127-140. [CrossRef]

32. Schleicher, A. (Ed.) Preparing Teachers and Developing School Leaders for the 21st Century: Lessons from around the World; OECD Publishing: Paris, France, 2012.

33. Berliner, D.C. Learning About and Learning from Expert Teachers. Int. J. Educ. Res. 2001, 35, 463-482. [CrossRef]

34. Fenstermacher, G.D.; Richardson, V. On Making Determinations of Quality in Teaching. Teach. Coll. Rec. 2005, 107, 186-213. [CrossRef]

35. Shavelson, R.J. On an Approach to Testing and Modeling Competence. Educ. Psychol. 2013, 48, 73-86. [CrossRef]

36. Edwards, A. Relational Agency: Learning to Be a Resourceful Practitioner. Int. J. Educ. Res. 2005, 43, 168-182. [CrossRef]

37. Sachs, J. The Activist Professional. J. Educ. Chang. 2000, 1, 77-94. [CrossRef]

38. Turnbull, M. Student Teachers Professional Agency in the Practicum: Myth or Possibility? Ph.D. Thesis, Curtin University of Technology, Perth, Australia, 2002, unpublished.

39. Turnbull, M. Student Teacher Professional Agency in the Practicum. Asia-Pac. J. Teach. Educ. 2005, 33, 195-208. [CrossRef]

40. Pietarinen, J.; Pyhältö, K.; Soini, T.; Salmela-Aro, K. Reducing Teacher Burnout: A Socio-contextual Approach. Teach. Teach. Educ. 2013, 35, 62-72. [CrossRef]

41. Pyhältö, K.; Pietarinen, J.; Soini, T. Comprehensive School Teachers' Professional Agency in Large-scale Educational Change. J. Educ. Chang. 2012, 15, 303-325. [CrossRef]

42. Edwards, A.; D'Arcy, C. Relational Agency and Disposition in Sociocultural Accounts of Learning to Teach. Educ. Rev. 2004, 56, 147-155. [CrossRef] 
43. Kwakman, K. Factors Affecting Teachers' Participation in Professional Learning Activities. Teach. Teach. Educ. 2003, 19, 149-170. [CrossRef]

44. Pyhältö, K.; Pietarinen, J.; Soini, T. Do Comprehensive School Teachers Perceive Themselves as Active Professional Agents in School Reforms? J. Educ. Chang. 2012, 13, 95-116. [CrossRef]

45. Pyhältö, K.; Pietarinen, J.; Toom, A.; Haverinen, K.; Beijaard, D.; Soini, T. Trajectories of Secondary Teacher Students' Professional Agency in Classroom. Eur. J. Teach. Educ.. submitted.

46. Emirbayer, M.; Mische, A. What is Agency? Am. J. Sociol. 1998, 103, 962-1023. [CrossRef]

47. Lipponen, L.; Kumpulainen, K. Acting as Accountable Authors: Creating Interactional Spaces for Agency Work in Teacher Education. Teach. Teach. Educ. 2011, 27, 812-819. [CrossRef]

48. Van Eekelen, I.M.; Vermunt, J.D.; Boshuizen, H.P.A. Exploring Teachers' Will to Learn. Teach. Teach. Educ. 2006, 22, 408-423. [CrossRef]

49. Hakkarainen, K.; Paavola, S.; Lipponen, L. From Communities of Practice to Innovative Knowledge Communities. LLine Lifelong Learn. Eur. 2004, 9, 74-83.

50. Rogoff, B.; Matusov, E.; White, C. Models of Teaching and Learning: Participation in a Community of Learners. In Handbook of Education and Human Development: New Models of Learning, Teaching, and Schooling; Olson, D., Torrance, N., Eds.; Basil Blackwell: London, UK, 1996; pp. 388-414.

51. Jääskelä, P.; Poikkeus, A.-M.; Vasalampi, K.; Valleala, U.M.; Rasku-Puttonen, H. Assessing Agency of University Students: Validation of the AUS Scale. Stud. High. Educ. 2016. [CrossRef]

52. Beijaard, D. Teachers' Prior Experiences and Actual Perceptions of Professional Identity. Teach. Teach. Theory Pract. 1995, 1, 281-294. [CrossRef]

53. Heikonen, L.; Pietarinen, J.; Toom, A.; Soini, T.; Pyhältö, K. The Development of Student Teachers' Sense of Professional Agency in the Classroom During Teacher Education. Learn. Res. Pract. 2020. [CrossRef]

54. Sannino, A.; Engeström, Y.; Lemos, M. Formative Interventions for Expansive Learning and Transformative Agency. J. Learn. Sci. 2016. [CrossRef]

55. Greeno, J.G. Authoritative, Accountable Positioning and Connected, General knowing: Progressive Themes in Understanding Transfer. J. Learn. Sci. 2006, 15, 537-547. [CrossRef]

56. Arnold, J.; Clarke, D.J. What Is 'Agency'? Perspectives in Science Education Research. Int. J. Sci. Educ. 2014, 36, 735-754. [CrossRef]

57. Pyhältö, K.; Pietarinen, J.; Soini, T. Teachers' Professional Agency and Learning-From Adaption to Active Modification in the Teacher Community. Teach. Teach. Theory Pract. 2015, 21, 811-830. [CrossRef]

58. Edwards, A. Recognizing and Realizing Teachers' Professional Agency. Teach. Teach. Theory Pract. 2015, 21, 779-784. [CrossRef]

59. Eteläpelto, A.; Vähäsantanen, K.; Hökkä, P.; Paloniemi, P. What is Agency? Conceptualizing Professional Agency at Work. Educ. Res. Rev. 2013, 10, 45-65. [CrossRef]

60. Day, C.; Elliot, B.; Kington, A. Reform, Standards and Teacher Identity: Challenges of Sustaining Commitment. Teach. Teach. Educ. 2005, 21, 563-577. [CrossRef]

61. Linnenbrink-Garcia, L.; Kempler Rogat, T.; Koskey, K.L.K. Affect and Engagement during Small Group Instruction. Contemp . Educ. Psychol. 2011, 36, 13-24. [CrossRef]

62. Conway, P.F.; Clark, C.M. The Journey Inward and Outward: A Reexamination of Fuller's Concerns-Based Model of Teacher Development. Teach. Teach. Educ. 2003, 19, 465-482. [CrossRef]

63. Edwards, A. Relational Agency in Professional Practice: A CHAT Analysis. ACTIO Int. J. Hum. Act. Theory 2007, 1, 1-17.

64. Beauchamp, C.; Thomas, L. New Teachers' Identity Shifts at the Boundary of Teacher Education and Initial Practice. Int. J. Educ. Res. 2011, 50, 6-13. [CrossRef]

65. Ball, D.L.; Forzani, F.M. The Work of Teaching and the Challenge for Teacher Education. J. Teach. Educ. 2009, 60, 497-511. [CrossRef]

66. Husu, J.; Toom, A.; Patrikainen, S. Guided reflection as a means to demonstrate and develop student teachers' reflective competencies. Reflective Pract. 2008, 9, 37-51. [CrossRef]

67. Saariaho, E.; Toom, A.; Soini, T.; Pietarinen, J.; Pyhältö, K. Student-teachers' and Pupils' Co-regulated Learning Behaviours in Authentic Classroom Situations in Teaching Practice. Teach. Teach. Educ. 2019. [CrossRef]

68. Lonka, K.; Ketonen, E. How to Make a Lecture Course an Engaging Learning Experience? Stud. Learn. Soc. 2012, 2, 63-74. [CrossRef]

69. Borko, H. Professional Development and Teacher Learning: Mapping the Terrain. Educ. Res. 2004, 33, 3-15. [CrossRef]

70. Grossman, P. The Teaching of Practice in Teacher Education. In Making a Difference: Challenges for Teachers, Teaching and Teacher Education; Butcher, J., McDonald, L., Eds.; Sense Publishers: Rotterdam, The Netherlands, 2007; pp. 55-65.

71. Donche, V.; Van Petegem, P. The Development of Learning Patterns of Student Teachers: A Cross-Sectional and Longitudinal Study. High. Educ. 2009, 57, 463-475. [CrossRef]

72. Korthagen, F.A.J. Situated Learning Theory and the Pedagogy of Teacher Education: Towards an Integrative View of Teacher Behavior and Teacher Learning. Teach. Teach. Educ. 2010, 26, 98-106. [CrossRef]

73. Heikkilä, A.; Lonka, K.; Nieminen, J.; Niemivirta, M. Relations between Teacher Students' Approaches to Learning, Cognitive and Attributional Strategies, Well-being and Study Success. High. Educ. 2012, 64, 455-471. [CrossRef]

74. Cochran-Smith, M. Policy, Practice, and Politics in Teacher Education; Corwin Press: Thousand Oaks, CA, USA, 2006.

75. Ketelaar, E.; Beijaard, D.; Boshuizen, H.P.A.; Den Brok, P.J. Teachers' Positioning Towards an Educational Innovation in the Light of Ownership, Sensemaking and Agency. Teach. Teach. Educ. 2012, 28, 273-282. [CrossRef] 